\title{
Effects of wildfires on peak discharges in watersheds
}

\author{
Maurizio Leopardi, Anna Rita Scorzini
}

Wildfires can alter the hydrological processes in watersheds resulting in increases in peak discharge - one of the most important hydrological variables used in water resources applications. It follows that standard methods used for assessing the rainfall runoff should be modified in order to model the potential changes in watershed response under post-fire conditions. However, no reliable methodology for quantitatively assessing the effects of wildfires on hydrological parameters (such as curve numbers or runoff coefficients) has been identified to date. The approaches currently used are usually site-specific, mainly based on personal experience or very simple empirical strategies, and therefore affected by a degree of uncertainty. This paper addresses the estimation of the Soil Conservation Service Curve Number (SCS-CN or CN) in the district of San Giuliano, L'Aquila (central Italy), a small urban basin recently affected by a wildfire leading to a significant reduction in forest cover. The effects of the fire on runoff were modeled by adjusting CNs according to existing approaches from the literature in order to perform a sensitivity analysis for post-fire conditions; this allowed to examine the effects of the variability in model input parameters (estimates of post-fire CNs) upon expected peak discharges related to different return period storms. The fire effect ratio, which can be seen as a global parameter for describing alterations in the watershed response due to fire, is calculated by dividing post-fire peak discharge by prefire peak discharge. For the present case study, this ratio ranged between 1.1 and 2.3, indicating the urgent need for quantitative research on the effects of wildfires on the hydrological variables affecting runoff calculations.

Keywords: Wildfire, Curve Number, Peak Discharge, Runoff, GIS

\section{Introduction}

It is recognized that wildfires can seriously alter the hydrological response of watersheds to precipitation, with increases in peak discharges and sediment yields. These changes can be attributed to several physical processes occurring during fires, which result in the reduction of interception and infiltration rates due to the destruction of canopy cover, the alteration of the hydraulic proprieties of soils, the creation of ash and consequent water repellence phenomena (DeBano et al

$\square$ Dipartimento di Ingegneria Civile, EdileArchitettura e Ambientale, Università degli Studi dell'Aquila, v. G. Gronchi 18, I-67100 L’Aquila (Italy)

(a), Anna Rita Scorzini

(annarita.scorzini@graduate.univaq.it)

Received: Sep 09, 2013 - Accepted: May 25, 2014

Citation: Leopardi M, Scorzini AR, 2015. Effects of wildfires on peak discharges in watersheds. iForest 8: 302-307 [online 201409-03] URL: http://www.sisef.it/iforest/ contents/?id=ifor1120-007

Communicated by: Luca Salvati
1998, Inbar et al. 1998, DeBano 2000, Robichaud 2000, Shakesby \& Doerr 2006, Onda et al. 2008, Malkinson \& Wittenberg 2011, Ebel et al. 2012, Stoof et al. 2012, Moody et al. 2013).

Post-fire measurements show that changes in peak discharges are usually larger than changes in runoff volumes (Hessling 1999, McLin et al. 2001, Moody \& Martin 2001, Canfield et al. 2005). For this reason, the unit-area peak discharge is considered to be the most sensitive parameter for the description of the modified watershed response after a wildfire (e.g., Rowe et al. 1954). More specifically, experimental analyses conducted both in Europe and in the United States indicate that the annual peak discharge in postfire conditions can increase by a factor generally ranging from 1.2 to 6.5 (Hoyt \& Troxell 1934, Anderson 1976, Hessling 1999, Loáiciga et al. 2001, Conedera et al. 2003, Rulli \& Rosso 2007, Pierson et al. 2008, Seibert et al. 2010) and can even exceed 100 in some cases (Campbell et al. 1977, Bolin $\&$ Ward 1987, Neary et al. 2003). However, there have been some case studies (Britton 1991, Aronica et al. 2002, Bart \& Hope 2010) in which little or no increase in postfire discharges were observed.
In general, the first years after the event are the most critical in terms of hydrological instability (Marques \& Mora 1992, Cerda 1998), even though in some cases an increased runoff discharge has been observed up to a decade following a wildfire (Inbar et al. 1998, Mayor et al. 2007). Rowe et al. (1954) analyzed how the ratio of unit-area peak discharge changed in pre- and post-fire conditions over 70 years in a case study in southern California; they measured as little as 2-fold increases for infrequent storms and as much as 40 -fold increases as a consequence of frequent storms. Such ratio tended to diminish year by year after fire occurrence, being the time required to recover to pre-fire conditions depending on fire severity, affected forest type and post-fire meteorological conditions (Keeley et al. 2005, Lentile et al. 2007, Moody et al. 2008, Diffendorfer et al. 2012). In light of these findings, it is evident that the standard rainfall-runoff methods applied in engineering practices need to be modified in order to model more accurately the change in watershed response following a fire (Ebel \& Moody 2013).

In the present study, the effects of a wildfire on the hydrological parameters used for calculating runoff are assessed for a small urban basin in central Italy (San Giuliano, L'Aquila). Specifically, peak discharges in both pre- and post-fire conditions were calculated using the SCS-CN method, which estimates runoff by considering soil types, land cover and the influence of previous soil moisture conditions. Fire effects on peak discharges were then modeled by adjusting $C N$ values according to existing approaches reported in the literature (Foltz et al. 2009).

A Geographic Information System (GIS) a powerful tool in hydrological modeling due to its capacity to handle large amounts of spatial and attribute data - was used for creating, managing and generating different layers and maps of aggregate hydrological parameters from different sources.

\section{Methods and materials}

\section{Study area}

The San Giuliano basin is part of the L'Aquila District hydrological system, bordered on the north by the Monti della Laga mountain range, on the east by the Gran Sasso Massif, on the south by the Monte Sirente range and on the west by the Monte Velino range. These form a natural barrier against atmospheric perturbations originating from the Adriatic and Tyrrhenian seas, resulting in a significant reduction in precipitation.

The basin can be divided in two sub-basins, whose characteristics are shown in Tab. 1: drainage area $A$, urbanization extent $A_{\text {urb }}$ (expressed as a percentage of the drainage 
Tab. 1 - Characteristics of the San Giuliano Basin. $\left(A_{\text {urb }}\right)$ : urbanization extent (in percentage of the drainage area, $A$ ).

\begin{tabular}{lllcc}
\hline Sub-basin & $\begin{array}{c}\boldsymbol{A} \\
{\left[\mathbf{k m}^{2}\right]}\end{array}$ & $\begin{array}{c}\boldsymbol{A}_{\text {urb }} \\
{[\mathbf{\%}]}\end{array}$ & $\begin{array}{c}\boldsymbol{H} \\
{[\mathbf{m} \text { a.s.l.] }}\end{array}$ & $\begin{array}{c}\boldsymbol{T}_{\mathbf{c}} \\
{[\mathbf{h}]}\end{array}$ \\
\hline Sub-basin 1 & 8.45 & 5.3 & 968 & 1.37 \\
Sub-basin 2 & 5.47 & 9 & 896 & 1.34 \\
\hline
\end{tabular}

Tab. 2 - Coefficients of the regional rainfall depth-duration equation.

\begin{tabular}{|c|c|c|c|c|c|c|}
\hline \multirow{2}{*}{$\begin{array}{c}\text { Coeffi- } \\
\text { cient }\end{array}$} & \multicolumn{3}{|c|}{ Sub-basin 1} & \multicolumn{3}{|c|}{ Sub-basin 2} \\
\hline & $50 y$ & $100 y$ & $200 y$ & $50 y$ & $100 y$ & $200 y$ \\
\hline$a$ & 40.188 & 44.607 & 49.023 & 40.068 & 44.514 & 48.944 \\
\hline$n$ & 0.283 & 0.275 & 0.269 & 0.271 & 0.263 & 0.256 \\
\hline
\end{tabular}

area), mean height $H$ and time of concentration $T_{\mathrm{c}}$, calculated using Giandotti's formula (Giandotti 1934).

A regionalization procedure was applied to overcome the problem related to the limited availability of hydrological measurements through space and time. For this reason, seven rain gauge stations located in the L'Aquila area were considered to determine the regional rainfall depth-duration equation $h=a t^{\mathrm{n}}$ (coefficients $a$ and $n$ are given in
Tab. 2) for three return-period storms (50, 100 and 200 years).

A topographic map (scale 1:5000), landcover map (based on Corine Land Cover classification) and soil map were used to delineate watershed borders, identify types of land-use and extract soil information, respectively.

\section{Modeling pre-fire conditions}

The SCS-CN (USDA 1986) model is one of the commonly used methods for estimating the surface runoff from watersheds. The infiltration losses are combined with surface storage by the equation (eqn. 1):

$$
Q=\frac{\left(P-I_{a}\right)^{2}}{\left(P-I_{a} 2 B S\right)}
$$

where $Q[\mathrm{~mm}]$ is the accumulated runoff or rainfall excess, $P[\mathrm{~mm}]$ is the rainfall depth and $I_{\mathrm{a}}[\mathrm{mm}]$ is the initial abstraction, which includes surface storage, interception and in-

Fig. 1 - Use of GIS for the calculation of area-weighted

$C N$ in the San Giuliano

basin. (a) Land cover map;

(b) hydrological soil group map; (c) $C N$ map.

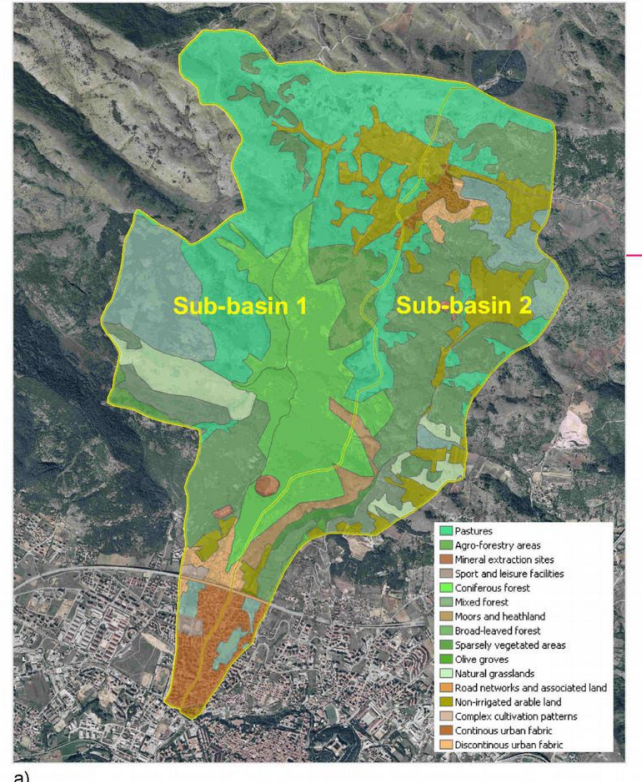

a)

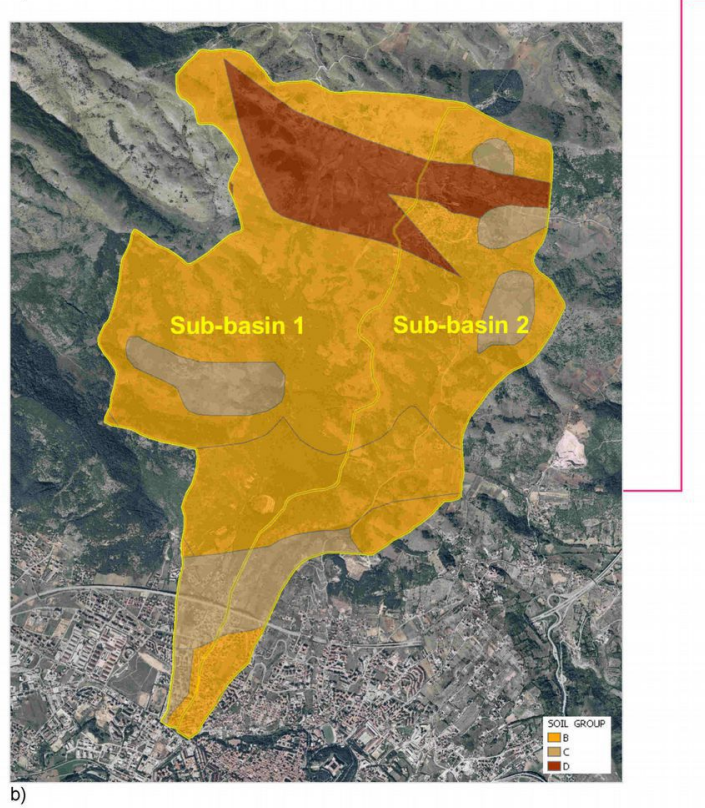

0

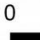

1

$3 \mathrm{~km}$ 
filtration prior to runoff in the watershed, as expressed by the empirical equation (eqn. 2):

$$
I_{a}=0.2 \cdot S
$$

The term $S$ is the potential maximum retention, given by (eqn. 3 ):

$$
S=25.4 \cdot\left(\frac{1000}{C N}-10\right)
$$

where $C N$ [dimensionless - ranging from 0 to $100]$ is derived from data reflecting land cover, hydrologic soil group (A, B, C and D) and antecedent soil moisture condition (AMC, an index of soil wetness - USDA 1986).

Area-weighted $C N$ s for the two sub-basins were computed using GIS software, according to the scheme shown in Fig. 1, by combining information from the land cover map (Fig. 1a) and the hydrologic soil group map (Fig. 1b), which was produced by assigning a particular hydrologic soil group (A, B, C or $\mathrm{D})$ depending on the soil's minimum infiltration rate. Subsequently, to create a $C N$ map (Fig. 1c), the hydrologic soil group field from the soil theme and the land use field from the land cover theme were selected for intersection. After this operation, a new polygon shapefile indicating the merged soil hydrologic group and land cover themes was generated. In accordance with USDA (1986), the appropriate $C N$ value was assigned to each polygon of this new map under the hypothesis of AMC II, which is essentially an average moisture condition. Data extracted from the new polygon attribute table were used to compute area-weighted $C N \mathrm{~s}$ of the study area, equal to 69.4 for sub-basin 1 and 70.0 for sub-basin 2 .

\section{Modeling post-fire conditions}

A serious wildland-urban interface fire recently destroyed $30 \%$ and $10 \%$ of the forest area in sub-basins 1 and 2, respectively. As shown in Fig. 2, about three years after the event, the largest difference between burned and unburned areas is represented by the lack of grass cover and underbrush.

Peak discharge was expected to increase as a consequence of the fire. Post-fire conditions were then modeled by adjusting pre-fire $C N \mathrm{~s}$ to post-fire $C N \mathrm{~s}$ as a function of burned area and fire severity (low, moderate or high).

Despite the general consensus on the issue that peak discharge tends to increase as a result of fire, at present there is no consistent methodology to estimate post-fire $C N \mathrm{~s}$, since the analysis of the hydrologic response of watersheds to wildfire is still a topic under investigation (Springer \& Hawkins 2005) and limited to few studies have been carried out in the United States. Currently, existing approaches are not supported by post-fire
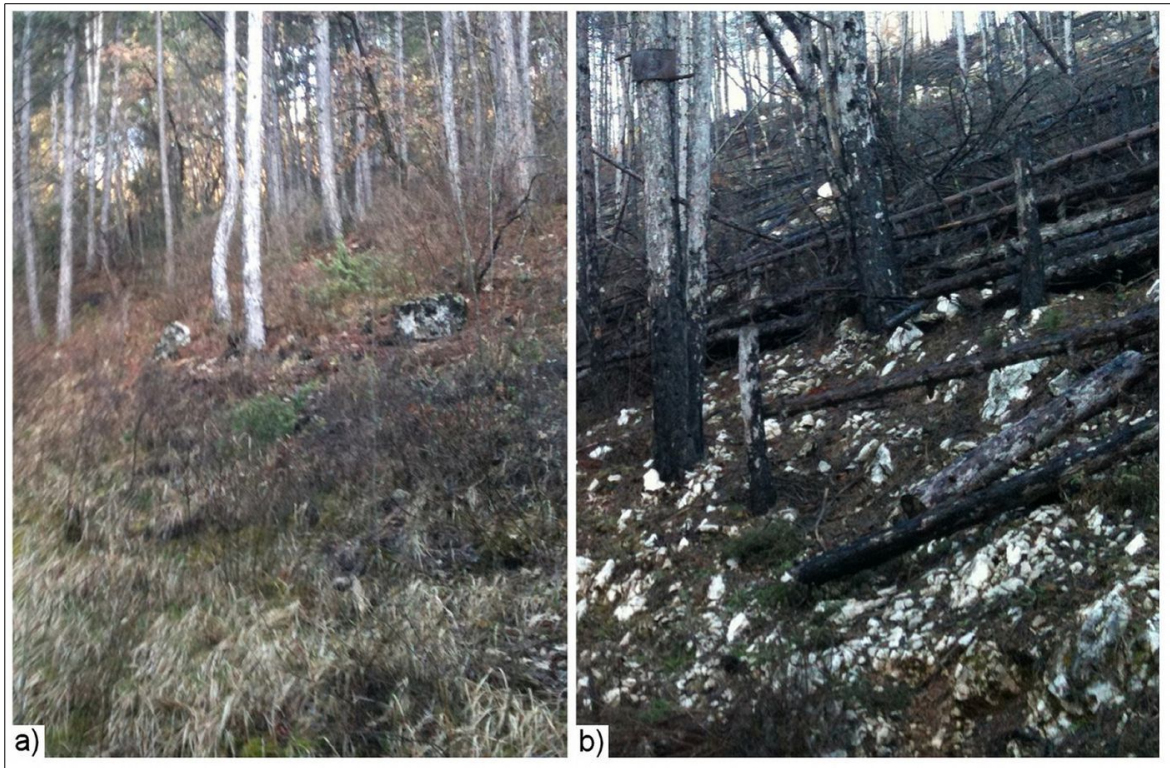

Fig. 2 - Effect of fire in San Giuliano basin. (a) Unburned areas; (b) burned areas.

data analysis and are mainly based on practical rules and/or experience (Foltz et al. 2009). For example, some of these approaches are reported in the Burned Area Emergency Response (BAER) manual (Foltz et al. 2009) and include the following:

(1) Wildfire Hydrologic Impact (WHI - Livingston et al. 2005): post-fire $C N$ s are calculated as a function of the WHI classification (severe/moderate/low, related to the percentage of the sub-basin characterized by high soil burn severity) and pre-fire $C N \mathrm{~s}$.

(2) BAER Hydrology Special Report (Higginson \& Jarnecke 2007):

- High burn severity: $C N_{\text {post }}=C N_{\text {pre }}+15$

- Moderate burn severity: $C N_{\text {post }}=C N_{\text {pre }}+$ 10

- Low burn severity: $C N_{\text {post }}=C N_{\text {pre }}+5$

where $C N_{\text {post }}$ is the post-fire $C N$ and $C N_{\text {pre }}$ is the pre-fire $C N$.

(3) BAER Design Storms (Foltz et al. 2009):

- High burn severity with water repellent soils: $C N_{\text {post }}=95$

- High burn severity without water repellent soils: $C N_{\text {post }}=90$ to 91

- Moderate burn severity with water repellent soils: $C N_{\text {post }}=90$

- Moderate burn severity without water repellent soils: $C N_{\text {post }}=85$

- Low burn severity: $C N_{\text {post }}=C N_{\text {pre }}+5$

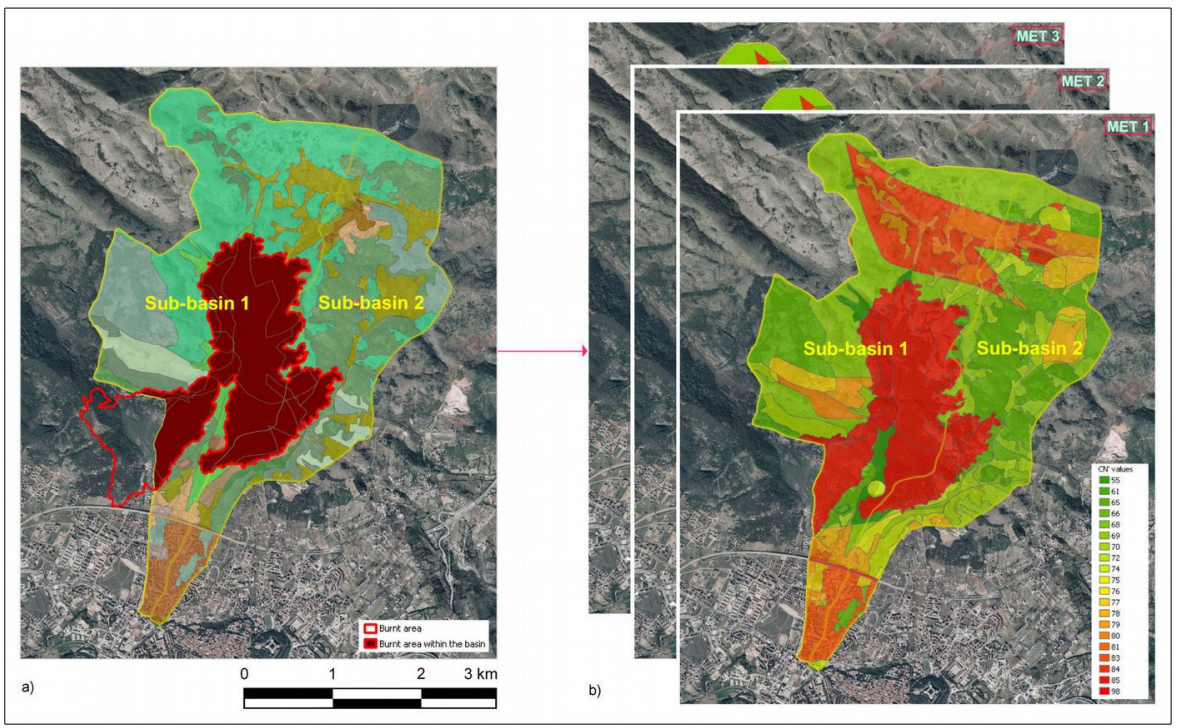

Fig. 3 - Use of GIS for the calculation of $C N$ in post-fire condition. (a) Overlay of burned area map on land cover map; (b) Maps with post-fire $C N$ values estimated according to the different approaches. 
It is worth noting that these rules are sitespecific, strictly applicable to the regions in which they were developed, or for areas characterized by similar precipitation regimes and pre-fire $C N$ values.

For the case study under investigation, since neither a detailed burn severity map nor site-specific studies for the evaluation of post-fire $C N \mathrm{~s}$ were available, all three approaches listed above from the BAER Manual were used, considering each level of burn severity, to calculate the modified $C N \mathrm{~s}$ (under the simplifying hypothesis that the whole burnt area would have been affected to the same degree of severity); this was done in order to perform a sensitivity analysis for post-fire conditions while examining the effects of the variability in model input parameters (estimates of post-fire $\mathrm{CNs}$ according to existing rules from the literature) upon model output (peak discharges related to different return period storms in post-fire conditions).

Tab. 3 - Pre-fire calculations for the San Giuliano basin.

\begin{tabular}{llccc}
\hline Sub-basin & $\boldsymbol{C N}$ & $\begin{array}{c}\boldsymbol{Q}_{\mathbf{5 0}} \\
{\left[\mathbf{m}^{\mathbf{3}} / \mathbf{s}\right]}\end{array}$ & $\begin{array}{c}\boldsymbol{Q}_{\mathbf{1 0 0}} \\
{\left[\mathbf{m}^{\mathbf{3}} / \mathbf{s}\right]}\end{array}$ & $\begin{array}{c}\boldsymbol{Q}_{\mathbf{2 0 0}} \\
{\left[\mathbf{m}^{\mathbf{3}} / \mathbf{s}\right]}\end{array}$ \\
\hline Sub-basin 1 & 69.4 & 6 & 8.6 & 11.5 \\
Sub-basin 2 & 70 & 4.1 & 5.8 & 7.8 \\
\hline
\end{tabular}

Tab. 4 - Post-fire calculations for sub-basin 1. (Met.): the methodology used.

\begin{tabular}{lllcccccc}
\hline \multirow{2}{*}{ Met. } & Burn & & \multicolumn{2}{c}{$\mathbf{5 0 y}$} & \multicolumn{2}{c}{$\mathbf{1 0 0 y}$} & \multicolumn{2}{c}{$\mathbf{2 0 0 y}$} \\
\cline { 5 - 9 } & severity & $\boldsymbol{C N}$ & $\begin{array}{c}\boldsymbol{Q} \\
{\left[\mathbf{m}^{3} / \mathbf{s}\right]}\end{array}$ & $\begin{array}{c}\boldsymbol{f} \text { re. } \\
\text { ratio }\end{array}$ & $\begin{array}{c}\boldsymbol{Q} \\
{\left[\mathbf{m}^{3} / \mathbf{s}\right]}\end{array}$ & $\begin{array}{c}\boldsymbol{f} . \boldsymbol{e} . \\
\text { ratio }\end{array}$ & $\begin{array}{c}\boldsymbol{Q} \\
{\left[\mathbf{m}^{3} / \mathbf{s}\right]}\end{array}$ & $\begin{array}{c}\boldsymbol{f} . \boldsymbol{e} . \\
\text { ratio }\end{array}$ \\
\hline WHI & Severe & 79.3 & 16.6 & 2.78 & 21.1 & 2.46 & 25.9 & 2.25 \\
& Moderate & 75 & 11.2 & 1.87 & 14.8 & 1.73 & 18.7 & 1.63 \\
& Low & 71.6 & 7.7 & 1.3 & 10.7 & 1.25 & 14.1 & 1.22 \\
\hline BAER & High & 73.8 & 9.9 & 1.66 & 13.3 & 1.55 & 17 & 1.48 \\
HSR & Moderate & 72.3 & 8.5 & 1.42 & 11.6 & 1.35 & 15.1 & 1.31 \\
& Low & 70.9 & 7.2 & 1.2 & 10 & 1.17 & 13.2 & 1.15 \\
\hline BAER & High w.w.r.soil & 79.4 & 16.8 & 2.81 & 21.3 & 2.49 & 26.1 & 2.27 \\
DS & High w/o.w.r.soil & 78 & 14.8 & 2.48 & 19 & 2.22 & 23.5 & 2.04 \\
& Mod. w.w.r.soil & 78 & 14.8 & 2.48 & 19 & 2.22 & 23.5 & 2.04 \\
& Mod.w/o.w.r.soil & 76.5 & 13 & 2.17 & 16.9 & 1.97 & 21.1 & 1.83 \\
& Low & 70.9 & 7.2 & 1.2 & 10 & 1.17 & 13.2 & 1.15 \\
\hline
\end{tabular}

Tab. 5 - Post-fire calculations for sub-basin 2. (Met.): the methodology used.

\begin{tabular}{|c|c|c|c|c|c|c|c|c|}
\hline \multirow[b]{2}{*}{ Met. } & \multirow[b]{2}{*}{$\begin{array}{l}\text { Burn } \\
\text { severity }\end{array}$} & \multirow[b]{2}{*}{$C N$} & \multicolumn{2}{|c|}{$50 y$} & \multicolumn{2}{|c|}{$100 y$} & \multicolumn{2}{|c|}{$200 y$} \\
\hline & & & $\underset{\left[\mathrm{m}^{3} / \mathrm{s}\right]}{Q}$ & $\begin{array}{c}\text { f.e. } \\
\text { ratio }\end{array}$ & $\underset{\left[\mathbf{m}^{3} / \mathbf{s}\right]}{Q}$ & $\begin{array}{l}\text { f.e. } \\
\text { ratio }\end{array}$ & $\underset{\left[\mathrm{m}^{3} / \mathbf{s}\right]}{Q}$ & $\begin{array}{c}\text { f.e. } \\
\text { ratio }\end{array}$ \\
\hline \multirow[t]{3}{*}{ WHI } & Severe & 73.5 & 6.1 & 1.5 & 8.3 & 1.42 & 10.2 & 1.37 \\
\hline & Moderate & 71.2 & 4.7 & 1.15 & 6.6 & 1.12 & 8.7 & 1.11 \\
\hline & Low & 70.8 & 4.5 & 1.1 & 6.3 & 1.08 & 8.4 & 1.07 \\
\hline BAER & High & 71.6 & 4.9 & 1.21 & 6.9 & 1.18 & 9 & 1.16 \\
\hline \multirow[t]{2}{*}{ HSR } & Moderate & 71.2 & 4.6 & 1.14 & 6.5 & 1.12 & 8.6 & 1.10 \\
\hline & Low & 70.6 & 4.3 & 1.07 & 6.2 & 1.06 & 8.2 & 1.05 \\
\hline BAER & High w.w.r.soil & 73.6 & 6.1 & 1.51 & 8.3 & 1.43 & 10.7 & 1.37 \\
\hline \multirow[t]{4}{*}{ DS } & High w/o.w.r.soil & 73 & 5.8 & 1.43 & 7.9 & 1.36 & 10.3 & 1.31 \\
\hline & Mod. w.w.r.soil & 73 & 5.8 & 1.43 & 7.9 & 1.36 & 10.3 & 1.31 \\
\hline & Mod.w/o.w.r.soil & 72.5 & 5.5 & 1.34 & 7.5 & 1.29 & 9.8 & 1.26 \\
\hline & Low & 70.6 & 4.3 & 1.07 & 6.2 & 1.06 & 8.2 & 1.05 \\
\hline
\end{tabular}

dered as a global parameter for describing the altered watershed response to fire.

Results showed that area-weighted $C N \mathrm{~s}$ in post-fire conditions vary depending on the approach used: Wildfire Hydrologic Impact (WHI), Baer Hydrology Special Report (BAER HSR) or BAER Design Storm (BAER DS), for each different fire severity. For sub-basin 1, the $C N$ s ranged (considering low to high burn severity) from $\sim 71$ to $\sim 78$, while they ranged from $\sim 70.5$ to $\sim 72$ for sub-basin 2 . This variability was also reflected in fire effect ratios, which ranged from $\sim 1.2$ to $\sim 2.8$ (for sub-basin 1) and from $\sim 1.1$ to $\sim 1.5$ (for sub-basin 2 ) for the 50 -year return period storm, diminishing to $\sim 1.2-2.3$ (for sub-basin 1) and 1.1-1.4 (for sub-basin 2 ) for the 200-year return period storm.

It should be noted that these estimates refer to the first years after the fire, since post-fire $C N$ s are expected to attenuate during the recovery period, gradually approaching the pre-fire values, correlated with a proportional reduction in the fire effect ratio. Obviously, the recovery period is tightly related to the rate of vegetation recovery and further depends on the types of plant species existing in pre-fire conditions, on the hydrological characteristics of the area and on fire severity.

The high variability of the results obtained using different approaches indicates the urgent need to perform validation analyses and/or new experimental observations in order to increase the accuracy of the estimated post-fire $C N$ values and consequent runoff.

\section{Conclusions}

The effects of wildfires on the hydrological response of watersheds can be modeled by adjusting the hydrological parameters involved in traditional rainfall-runoff models to account for changes induced by the fire (e.g., $\mathrm{CNs}$ or runoff coefficients adjusted as a function of burned area and fire severity). Various approaches have been reported in the literature; however, due to the lack of any consistent and verified guidelines, the selection of the method to use and the way in which parameters are adjusted to account for post-fire conditions entails a substantial degree of subjectivity, affecting the reliability of the model output.

For the investigated area, since local studies allowing post-fire $C N \mathrm{~s}$ to be calculated with a high degree of certainty were not available (as in many other areas affected by wildfires), we analyzed the variability in the estimates of post-fire discharge obtained using the various approaches reported in the literature for modeling post-fire conditions. Given the subjectivity involved in choosing one approach or another, the potential range of results obtainable considering the different approaches was assessed. The range of fire effect ratios calculated using the afore- 
mentioned methodologies was very large (from 1.1 to 2.3 ), indicating the unreliability of estimates when it is not possible to verify the output in the field. Further experimental research is necessary in order to reduce the gap in the knowledge required to accurately estimate and validate post-fire hydrological parameters.

\section{References}

Anderson HW (1976). Fire effects on water supply, floods, and sedimentation. In: Proceedings of the " $15^{\text {th }}$ Annual Tall Timbers Fire Ecology Conference: Pacific Northwest". Portland (OR, USA) 16-17 Oct 1974. Tall Timbers Research Inc., Tallahassee, FL, USA, pp. 249-260.

Aronica G, Candela A, Santoro M (2002). Changes in the hydrological response of two Sicilian basins affected by fire. In: Proceedings of the " 4 th International FRIEND Conference". Cape Town (South Africa) 18-22 March 2002. IAHS Publ. no. 274, pp. 163-169.

Bolin SB, Ward TJ (1987). Recovery of a New Mexico drainage basin from a forest fire. In: Proceedings of the "Vancouver Symposium, Forest Hydrology and Watershed Management". Vancouver (BC, Canada) 9-22 Aug 1987. IAHSAISH Publ. no. 167, pp. 191-198.

Bart R, Hope A (2010). Streamflow response to fire in large catchments of a Mediterranean-climate region using paired-catchment experiments. Journal of Hydrology 388:370-378. - doi: 10.101 6/j.jhydrol.2010.05.016

Britton DL (1991). Fire and the chemistry of a South African mountain stream. Hydrobiologia 218: 177-192. - doi: 10.1007/BF00038834

Campbell RE, Baker MB, Ffolliott PF, Larson FR, Avery CC (1977). Wildfire effects on a ponderosa pine ecosystem: an Arizona case study. Research Paper RM-191, Rocky Mountain Research Station, USDA Forest Service, Fort Collins, CO, USA, pp. 12.

Canfield HE, Goodrich DC, Burns IS (2005). Application of models to predict post-fire runoff and sediment transport at the watershed scale in southwestern forests. In: Proceedings of the "2005 Watershed Management Conference Managing Watersheds for Human and Natural Impacts: Engineering, Ecological, and Economic Challenges" (Moglen GE ed). American Society of Civil Engineers, Reston, VA, USA, pp. 1-12.

Cerda A (1998). Changes in overland flow and infiltration after a rangeland fire in Mediterranean scrubland. Hydrological Processes 12 (7): 10311042. - doi: 10.1002/(ISSN)1099-1085

Conedera M, Peter L, Marxer P, Forster F, Rickenmann D, Re L (2003). Consequences of forest fires on the hydrogeological response of mountain catchments: a case study of the Riale Buffaga, Ticino, Switzerland. Earth Surf Process Landforms 28: 117-129. - doi: 10.1002/esp.425 DeBano LF, Neary DG, Ffolliott PF (1998). Fire's effects on ecosystems. John Wiley and Sons, New York, USA, pp. 338. [online] URL: http:// books.google.com/books? id =cFxtriC2EDkC DeBano LF (2000). The role of fire and soil heat- ing on water repellency in wildland environments: a review. Journal of Hydrology 231-232: 195-206. - doi: 10.1016/S0022-1694(00)001943

Diffendorfer J, Fleming GM, Tremor S, Spencer W, Beyers JL (2012). The role of fire severity, distance from fire perimeter and vegetation on post-fire recovery of small-mammal communities in chaparral. International Journal of Wildland Fire 21:436-448. - doi: 10.1071/WF10060

Ebel BA, Moody JA, Martin DA (2012). Hydrologic conditions controlling runoff generation immediately after wildfire. Water Resources Research 48 (3): W03529. - doi: 10.1029/2011WR 011470

Ebel BA, Moody JA (2013). Rethinking infiltration in wildfire-affected soils. Hydrological Processes 27: 1510-1514. - doi: 10.1002/hyp.9696

Foltz RB, Robichaud PR, Rhee H (2009). A synthesis of post-fire road treatments for BAER teams: methods, treatment effectiveness, and decision making tools for rehabilitation. Gen. Tech. Rep. RMRS-GTR-228, Rocky Mountain Research Station, USDA Forest Service, Fort Collins, CO, USA, pp. 152.

Giandotti M (1934). Previsione delle piene e delle magre dei corsi d'acqua [Estimation of flood and drought discharges in natural streams]. Istituto Poligrafico dello Stato 8: 107-117. [in Italian]

Hessling M (1999). Hydrological modelling and pair basin study of Mediterranean catchments. Physics and Chemistry of the Earth, Part B: Hydrology, Oceans and Atmosphere 24 (1-2): 5963. - doi: 10.1016/S1464-1909(98)00012-4

Higginson B, Jarnecke J (2007). Salt Creek BAER-2007 burned area emergency response. Hydrology Specialist Report, Uinta National Forest, Provo, UT, USA, pp. 11.

Hoyt WG, Troxell HC (1934). Forest and stream flow. Transactions of the American Society of Civil Engineers 99: 1-30. [online] URL: http:// cedb.asce.org/cgi/WWWdisplay.cgi?276879

Inbar M, Tamir M, Wittenberg L (1998). Runoff and erosion processes after a forest fire in Mount Carmel, a Mediterranean area. Geomorphology 24: 17-33. - doi: 10.1016/S0169-555X(97)00098 $-6$

Keeley JE, Fotheringham CJ, Baer-Keeley M (2005). Determinants of postfire recovery and succession in Mediterranean-climate shrublands of California. Ecological Applications 15 (5): 1515-1534. - doi: 10.1890/04-1005

Lentile LB, Morgan P, Hudak AT, Bobbitt MJ, Lewis SA, Smith AMS, Robichaud PR (2007). Post-fire burn severity and vegetation response following eight large wildfires across the western United States. Fire Ecology 3 (1): 91-108. - doi: 10.4996/fireecology.0301091

Livingston RK, Earles TA, Wright KR (2005). Los Alamos post-fire watershed recovery: a curve-number-based evaluation. In: Proceedings of the "2005 Watershed Management Conference - Managing Watersheds for Human and Natural Impacts: Engineering, Ecological, and Economic Challenges" (Moglen GE ed). American Society of Civil Engineers, Reston, VA,
USA, pp. 471-481. - doi: 10.1061/40763(178)41 Loáiciga HA, Pedreros D, Roberts D (2001). Wildfire-streamflow interactions in a chaparral watershed. Advances in Environmental Research 5: 295-305. - doi: 10.1016/S1093-0191(00)0006 4-2

Malkinson D, Wittenberg L (2011). Post fire induced soil water repellency - modeling short and long-term processes. Geomorphology 125: 186192. - doi: 10.1016/j.geomorph.2010.09.014

Marques MA, Mora E (1992). The influence of aspect on runoff and soil loss in a Mediterranean burnt forest (Spain). Catena 19: 333-344. - doi: 10.1016/0341-8162(92)90007-X

Mayor AG, Bautista S, Llovet J, Bellot J (2007).

Post-fire hydrological and erosional responses of a Mediterranean landscape: seven years of catchment-scale dynamics. Catena 71: 68-75. - doi: 10.1016/j.catena.2006.10.006

McLin SG, Springer EP, Lane LJ (2001). Predicting floodplain boundary changes following the Cerro Grande wildfire. Hydrological Processes 15 (15): 2967-2980. - doi: 10.1002/hyp.385

Moody JA, Martin DA (2001). Post-fire, rainfall intensity-peak discharge relations for three mountainous watersheds in the western USA. Hydrological Processes 15: 2981-2993. - doi: 10.1002/hyp.386

Moody JA, Martin DA, Haire SL, Kinner DA (2008). Linking runoff response to burn severity after a wildfire. Hydrological Processes 22: 2063-2074. - doi: 10.1002/hyp.6806

Moody JA, Shakesby RA, Robichaud PR, Cannon SH, Martin DA (2013). Current research issues related to post-wildfire runoff and erosion processes. Earth-Science Reviews 122: 10-37. - doi: 10.1016/j.earscirev.2013.03.004

Neary DG, Gottfried GJ, Ffolliott PF (2003). Postwildfire watershed flood responses. In: Procedings of the " $2^{\text {nd }}$ International Fire Ecology and Fire Management Congress". Orlando (Florida) 16-20 Nov 2003. Paper 1B7, pp. 1-7.

Onda Y, Dietrich WE, Brooker F (2008). Evolution of overland flow after a severe forest fire, Point Reyes, California. Catena 72: 13-20. - doi: 10.1016/j.catena.2007.02.003

Pierson FB, Robichaud PR, Moffet CA, Spaeth KE, Hardegree SP, Clark PE, Williams CJ (2008). Fire effects on rangeland hydrology and erosion in a steep sagebrush-dominated landscape. Hydrological Processes 22: 2916-2929. doi: 10.1002/hyp.6904

Robichaud PR (2000). Fire effects on infiltration rates after prescribed fire in northern Rocky Mountain forests, USA. Journal of Hydrology 231-232: 220-229. - doi: 10.1016/S0022-1694 (00)00196-7

Rowe PB, Countryman CM, Storey HC (1954). Hydrologic analysis used to determine effects of fire on peak discharge and erosion rates in Southern California watersheds. USDA Water Resources Center Archives, University of California, Berkeley, CA, USA, pp. 49.

Rulli MC, Rosso R (2007). Hydrologic response of upland catchments to wildfires. Advances in Water Resources 30: 2072-2086. - doi: 10.1016/ 
j.advwatres.2006.10.012

Seibert J, McDonnell JJ, Woodsmith RD (2010). Effects of wildfire on catchment runoff response: a modelling approach to detect changes in snowdominated forested catchments. Hydrology research 41: 378-390. - doi: 10.2166/nh.2010.036 Shakesby RA, Doerr SH (2006). Wildfire as hydrological and geomorphological agent. EarthScience Reviews 74: 269-307. - doi: 10.1016/j. earscirev.2005.10.006
Springer EP, Hawkins RH (2005). Curve number and peakflow responses following the Cerro Grande fire on a small watershed. In: Proceedings of the "2005 Watershed Management Conference - Managing Watersheds for Human and Natural Impacts: Engineering, Ecological, and Economic Challenges" (Moglen GE ed). American Society of Civil Engineers, Reston, VA, USA, pp. 459-470. - doi: 10.1061/40763(178)40 Stoof CR, Vervoort RW, Iwema J, van den Elsen
E, Ferreira AJD, Ritsema CJ (2012). Hydrological response of a small catchment burned by experimental fire. Hydrology and Earth System Sciences 16 (2): 267-285. - doi: 10.5194/hess-1 6- 267-2012

USDA (1986). Urban hydrology for small watersheds. Technical Release 55, USDA, Washington, DC, USA, pp. 164. 